\title{
Children Picture-Book Series on Exploring the Causes of Low Self-Esteem Issues in Children and the Positive Effects after Overcoming Them
}

\author{
Graciela Adelia ${ }^{1}$, Stefanny Irawan ${ }^{2}$ \\ English Department, Faculty of Languages and Literature, Petra Christian University, Siwalankerto 121-131, \\ Surabaya 60236, Indonesia. \\ E-mail: m11416009@john.petra.ac.id ${ }^{1}$, stefanny@petra.ac.id²
}

\begin{abstract}
This paper discusses creating children picture-book stories which highlight the issue of self-esteem in children, particularly exploring the causes of low self-esteem in children as well as what children get after regaining their self-esteem. Serving as the theoretical framework are Erik Erikson's Psychosocial Development, the concept of Praise Paradox, Body Image, and Colorism. In the first and second story, the main characters have low self-esteem because they feel unappreciated, and they later feel more loved and happier after overcoming their issues. In the third story, the main character has low self-esteem because she keeps receiving the wrong type of praise but later becomes calmer after overcoming her issue. The main characters in the fourth and fifth story have low self-esteem because of their appearances, but they will later be more confident and secure after overcoming their issues.
\end{abstract}

Keywords: Children Picture-Books, Self-Esteem, Psychosocial Development, Praise Paradox, Body Image, Colorism

\section{INTRODUCTION}

Self-esteem is an "evaluative aspect of self-knowledge that reflects the extent to which people like themselves and believe they are competent" (Hill, 2013, p. 2). There are two types of self-esteem which are high self-esteem and low self-esteem. High self-esteem is when an individual sees oneself as a decent person. Meanwhile, low self-esteem is when an individual tends to have a negative point of view as well as feel uncertain of oneself.

Self-esteem is important for mankind especially children because aside from radiating positivity into one's self, having a good sense of self-esteem also has other advantages. The first one is having confidence (Baumeister \& Vohs, 2018) where an individual can cope better with failures since he is not afraid to try again or to try something different in order to succeed. The second benefit is happiness. It is found that having self-esteem makes people feel good because they "bounce back from failure better than those with low self-esteem" (Baumeister \& Vohs, 2018, p. 138). In addition, self-esteemed individuals are also more likely to have high levels of "security, affection, energy availability, alertness, calmness, clear-mindedness, singleness of purpose, lack of restraint, and spontaneity" (Epstein as cited in Hill, 2013, p. 132).

In children, low self-esteem may lead to some detrimental effects. It can cause children to suffer from "psychological disorders, including major depression, anxiety disorder, eating disorders, sexual dysfunction, and pathological shame" (Leary \& Mac-Donald as cited in Hill, 2013, p. 132). Study has also proven that parents who perform wrong parenting might cause the child to "experience feelings of inferiority, anger, depression and incompetence" (Raina \& Bhan, 2013). 
Adelia, et al.: Children Picture-Book Series on Exploring the Causes of Low Self-Esteem Issues in Children and the Positive Effects after Overcoming Them

Low self-esteem in children appears as various negative aspects such as "neuroticism, sadness, hostility, anger, social anxiety, shame, guilt, embarrassment proneness, and loneliness" (Mruk as cited in Hill, 2013, p. 131-132). Not to forget, based on the book published by American Psychiatric Association, low self-esteem is included as one of the criteria into diagnosing the total of 24 mental disorders (O'brien et al as cited in Hill, 2013).

Cases of low self-esteem in children are prevalent, and Indonesia is not an exception. A research by Indonesia's Ministry of Women Empowerment and Child Protection showed that 56\% of Indonesian children, mostly female, suffer from low self-esteem (Prawira, 2018). The former Minister of Education and Culture of Indonesia, Muhadjir Effendy, also stated low self-esteem as one of the issues among Indonesian children (Ali, 2018). A similar statement also came from the current Minister of Education and Culture of Indonesia, Nadiem Makarim (Alika, 2019). Some of the causes for low self-esteem mentioned are Indonesian families' difficulties in encouraging their children to be confident, their environmental surroundings, maladjusted responsibilities, and physical appearances. As a result, children tend to have no courage to act and live in anxiety and shame (Ali, 2018). This shows that self-esteem is a relevant topic to pursue in this country.

This creative work is interested in exploring why children can develop low self-esteem and what they get after restoring their self-esteem. Readers, particularly children and the adult figures in their surroundings, would hopefully be more aware of this topic upon reading the stories and have a preliminary understanding of what they can do when it comes to the issue.

Children picture book is then chosen as the form as it is short, entertaining, yet beneficial and has a big market share. The decision was made after considering Indonesia's low reading interest compared to other countries (Pratiwi, 2018 and Damarjati, 2019). When the topic comes in the form of picture-book stories, children can easily read them, or parents can read them for their children. Either way, it presents some benefits such as learning about syntax, introducing new vocabularies, and even strengthening the children-parents bond (Worland, 2015). Next, its big market share is evident. Gramedia, as the biggest bookstore in Indonesia, sold the total of 10.1 million copies of picture books, beating other types of books (Wibisono, 2018). In 2017, children picture books dominated the Jakarta's The Big Bad Wolf, which is the biggest import book sales in Southeast Asia (Agnes, 2017). Internationally, picture books are also one of the books received positively by international markets like Frankfurt Book Fair (Makruf, 2016).

This picture-book stories target children aged six to eight, which is well within the age range of children picture book readership (Paul, 2009, p. 10). According to Healthwise, a nonprofit health organization established in 1975 , children from age six to eleven may face many new things from their surroundings (Self-esteem, 2018). As a result, there are many factors that can either build or tear their self-esteem (Self-esteem, 2018). By targeting children as young as six-year-old, these stories then introduce the self-esteem topic just when they may start to experience it in their life, making it more relevant to them than their younger counterparts.

Realistic fiction, or what is called literary realism in a more general sense, is used. The elements of the story such as the characters, events, and time are mirroring real life experiences. It is basically imagined stories with realness of life (Polson, 2018). Since the stories are meant to be handy for children, especially for them to understand their own self-esteem, realistic fiction is the apt genre so that children can relate as much as possible to those stories. 
For the theoretical framework, one theory and three concepts related to self-esteem are chosen. Erik Erikson's Eight Stages of Psychosocial Development is used for the first and second story. From Erikson's eight stages, the work mainly used stage number four and a little stage number three as background so that the readers know how the previous stage brings them to their current state. Stage number three occurs during the age three to five (Erikson as cited in Cherry, 2018). In this stage, children need to have initiative when it comes to planning their own activities, finishing their tasks, and facing challenges. It is best for children's caregivers (parents or other adults) to help the children by encouraging them to make the right choices. If caregivers discourage them instead, the children may feel ashamed and become overly dependent on others. However, when caregivers and children have different choices, it is best to give children their freedom to choose for them to successfully pass the stage (Erikson as cited in Cherry, 2018). After successfully going through stage three, children will move on to stage four which occurs during age five to eleven where children go through social interactions and develop a sense of pride regarding their abilities and achievements (Erikson as cited in Cherry, 2018). Children successful in stage number three are more likely to go through positive social interactions like receiving encouraging words from adults around them. However, the unsuccessful ones are less likely or will only receive little encouragements from their social interactions (Erikson as cited in Cherry, 2018). As a result, they will come to the realization that they are incompetent because their skills and efforts are not good enough and ends up with low self-esteem (Thill, 2019).

The Praise Paradox concept is used for the third story. Praise paradox itself "is when praises paradoxically lowered children's self-esteem instead of building it" (Brummelman et al, 2016, p. 111). In praise paradox, praises are divided into two which are person praise and process praise (Brummelman et al, 2016). Person praise is the type of praise that promotes a fixed mindset because it is used to praise someone for their ability or worth (Dweck as cited in Brummelman et al, 2016). As a result, children who receive person praise will "become concerned with how smart or worthy they are, seeking tasks that will prove these qualities and avoiding those that disprove them" (Brummelman et al, 2016, p. 112). For example, a person praise like "You're so good at playing piano" causes children to think that they must always be capable at playing piano at all cost. Consequently, they become unmotivated, avoid new challenges, and will feel deeply ashamed when they fail and or make mistakes (Brummelman et al, 2016).

On the other hand, the process praise is the type of praise that promotes a growth mindset because it focuses on the child's effort (Master, 2015.). It is discovered that "children who received process praise sought challenging tasks, and when they failed, they persisted longer, performed more optimally, and maintained their feelings of self-worth" (Brummelman et al, 2016, p. 113). Therefore, praising children with a process praise like "You've worked so hard in practicing piano" will not bother them and instead, can still make them feel positive even though they make mistakes because it shows that the efforts and process that they give to play the piano is valued (Master, 2015).

The second concept is called Body Image which is one of the concerning issues in this era (Bucchianeri as cited in Rodgers et al, 2014) and it is used for the fourth story. Body image itself is defined as "a person's perceptions, thoughts, and feelings about his or her body" (Grogan, 2017, p. 4). It also stands as a definition for many other conditions like weight satisfaction, size satisfaction, body esteem, body concern, and more. The journal Eating Behaviors claimed that children's mindset nowadays can be easily set into thinking that being thin and or muscular is a rewarding thing (Rodgers et al, 2014). This happens because media often promote certain body ideals (Rodgers et al, 2014). Things is even concerning for overweight children because "children with 
Adelia, et al.: Children Picture-Book Series on Exploring the Causes of Low Self-Esteem Issues in Children and the Positive Effects after Overcoming Them

overweight/obesity seem to have an elevated risk of low self-esteem in the domains of sports, physical appearance and peer engagement in particular" (Danielsen et al, 2011, p. 722). As a result, children with the mindset that has been affected by the media tend to have low self-esteem (Danielsen, 2011) and is often involved in body change behaviors like dieting and (Rodgers et al, 2014).

Colorism is the last concept used in the last story. According to Alice Walker, a feminist author, colorism is a global cultural practice because it is a "prejudice in favor of lighter skin color" (Knight, 2015, p. 46). Like body image, colorism is perpetuated by the media, especially since television nowadays "prefer to cast light-skinned people of color" (Knight, 2015, p. 46). As a result, colorism can cause "psychological, emotional, and physical damage once it becomes a part of the human psyche, it can lead to low self-esteem, low self-confidence, self-hatred, economic disadvantages and political disadvantages" (Duke \& Berry, 2011; Howard, 2011 as cited in Stamps, 2018).

The stories planned in this paper present five characters who struggle with their self-esteem. Ariana, Benny, Caroline, Dylan, and Elena are friends with one another and go to the same school. Each of them is facing their own low self-esteem issues which are doubting their abilities and physical appearances like skin color and weight. Once they overcome the said issues, they will regain their self-esteem and enjoy other positive effects.

\section{CONCEPT OF THE CREATIVE WORK}

\section{Theme}

Children can develop low self-esteem issues through their surroundings, be it from the adults around them or from the media. It is also important for them to overcome those issues in order to achieve greater positive effects in their life. Thus, the theme of this creative work is children's surroundings can cause low self-esteem issues and overcoming those issues can give some positive effects to children. The theme can be seen from the conflicts and endings that my main characters go through in the stories.

\section{Plot}

Since the creative work comes as a series of five books, there are five different plots.

How to Make Mama Proud

Ariana scores the highest for the science test at her class. At home, Ariana shows it to her mother, Theresa, who does not seem to care about it. Then Ariana learns about a science competition and wishes to join. When Ariana tells her mom, her mom says no and starts comparing Ariana to Sarah, her older sister who often helps in the kitchen. Ariana develops low self-esteem because her mom does not acknowledge her skill in science. One day, Ariana's mom hurts herself in the kitchen. Seeing that her sister cannot do anything about it, Ariana realizes that she can create a kitchen tool that can help her mom in the kitchen. She decides to join the competition and wins first place. This makes her mom proud and realizes Ariana's potential. Her mom now acknowledges her. Ariana now regain her self-esteem and can feel her mother's affection towards her. 
I Hate Art!

Benny's art club teacher, Ms. Ingrid, asks the students to draw what they like. When Benny is drawing, Ms. Ingrid looks at his drawing but does not say anything. She then praises one of her students' work. Benny decides to redraw his work, but Ms. Ingrid still does not praise him. Before the class is over, Ms. Ingrid announces that the art club will showcase their works in the upcoming art convention. Benny now has low self-esteem and does not want to join because he doubts his skills. Benny then decides to join other clubs, but wherever he goes, he always ends up with art. His best friends then cheer him up and he feels better. He decides to draw a sketch of his friends to show his gratitude and submit it to Ms. Ingrid. She compliments him and makes Benny regain his self-esteem and feel happier.

\section{Don’t Praise Me!}

Caroline is a session with her vocal coach to prepare for an upcoming singing project while her brother, Robin, is watching her from the beginning until the end. Afterwards, Robin showers her with person praise compliments. Caroline accepts them but feels burdened and thus develops low self-esteem because she does not want to disappoint Robin. On the day of the recording, Caroline becomes more nervous because Robin keeps giving her the person praise. When she is taking a break, she runs away and meets a girl. They sing together and the girl gives Caroline a process praise. Caroline feels better and decides to go back to find Robin and tell him what person praise does to her. Robin then apologizes and it makes Caroline feels better. She regains her self-esteem and becomes calmer when she sings in front of Robin.

I'm on A Diet

Dylan sees an advertisement of men and women with fit and muscular bodies. It amazes him and he is now self-conscious of his body. He realizes that he has the biggest body in his house in his class at school. This makes him develop a low self-esteem and decides to go on a diet. Dylan ends up not eating properly. One day, Dylan faints in the middle of his P.E class. He wakes up in the school clinic with Mr. Tony, who states his concern. Dylan tells the truth and Mr. Tony gives some advice to Dylan. Dylan comes to a better understanding and begins eating properly. He feels much better especially since he now understands about being fit and loving himself. He also restores his self-esteem and becomes confident with his look.

\section{My Cinnamon Skin}

It's Elena's first day in her new school and she feels embarrassed because she is the only one in class with tanned skin. She starts to have a low self-esteem and ignores her new friends, especially Caroline. At home, Elena tries to make her skin brighter, but none of her efforts work until one day, she sees a skin-whitening advertisement on TV. Elena asks her dad to buy it for her, but again, Elena is disappointed in the result. This makes Elena's low self-esteem worse and she pushes Caroline away even more. Elena later finds out that the founder of her school is an Ambonese just like her. Elena also discovers many other well-known people of color. Her discovery restores her self-esteem, and she feels more secure. The next day at school, she apologizes to Caroline and they become good friends. 
Adelia, et al.: Children Picture-Book Series on Exploring the Causes of Low Self-Esteem Issues in Children and the Positive Effects after Overcoming Them

\section{Characters}

Main characters:

Ariana, 8 years old, is the youngest daughter of two. She has long, dark-black hair and wears glasses. She is calm, very well-mannered, and is more matured than the kids her age. She lives with her Chinese descendant parents and older sister, but her father is rarely home because of his job. Unlike most of her friends, Ariana loves studying. Her most favorite subject is Science because she finds it fun especially when learning about new facts and trivia about human's body, nature, and planets.

Benny, 8 years old, is a bright boy and only child of divorced parents. His parents are still in good terms and they take turn in taking care of Benny during their busy working life. Benny's mother is a famous painter and Benny takes after his mother's talent. Ever since he was just two years old, he has always been so interested in art. Whenever he sees his mother painting, Benny would like to join and would cry when his father tried to carry him away. Benny joins the art club every Monday after school.

Caroline, 8 years old, is the youngest child of two of a Manadonese mother and an American father. She likes pink and ribbons, has dirty blonde hair, and brown doe eyes. She lives with her grandmother and her much older brother, Robin. She is very adorable and has the voice of an angel. Caroline has joined and won a lot of singing competitions. Despite her achievements and talent, Caroline is a humble and friendly child.

Dylan, 8 years old, lives with his mom, dad, and older brother. His mom loves cooking, and his dad was once a well-known basketball player. Just like his parents, Dylan loves cooking and eating, and he is also taller and heavier for kids his age. Dylan is quiet, fun, and the happiest when he eats.

Elena, 9 years old, is a girl from Ambon who has just moved to town and enrolled in the same school as the other four main characters. Her mother has passed away, and she only lives with her father and older sister. Elena moves often because her father's job requires constant relocation. This causes Elena to stay a grade behind in school. Elena likes socializing but she is too shy to try. She is a curious little girl who has a lot of interest in new things, but she becomes really quiet around new people.

Supporting characters:

Each of the supporting characters from these five stories has their own important role in their respective story.

Theresa, 34 years old, is Ariana's mother. She is a 34-year-old housewife who runs an Indonesian traditional snack business from home. She values hard working spirit, dreams that her business will keep growing, and that one of her daughters, possibly Sarah, will be able to take over once she retires. She is the reason Ariana develops low self-esteem.

Sarah, 11 years old, is Ariana's older sister. She is the opposite of Ariana. Studying is her least favorite thing to do but she still tries to have decent grades in school. In her free time, she likes 
helping her mother in the kitchen. She has long black hair just like Ariana, but she always ties them up because Theresa has taught her to do so since the first time she helped Theresa in the kitchen.

Ms. Ingrid, 41 years old, is Benny's art teacher from Canada. She has been living in Indonesia for ten years and has been teaching in the art club for five years. She speaks Indonesian but since she deems her pronunciation inferior for the class, she prefers teaching in English. She is chubby and has ginger colored curly hair. She adores batik so much. She is the reason why Benny develops low self-esteem.

Robin, 25 years old, is Caroline's older brother who really loves her. He calls Caroline princess and loves to shower her with smooches. A year after he enrolled in National University of Singapore, he dropped out and returned to Indonesia. Now, he lives in his parents' house to take care of his grandma and Caroline. He is the reason why Caroline develops low self-esteem.

Mr. Tony, 29 years old, is Dylan's new P.E teacher. Although he has only been teaching for three months, most students have already claimed him as their favorite teacher because he is very fun and looks like Dwayne Johnson, which is cool according to the kids. He helps Dylan to better understand about being fit.

\section{Conflict}

There are two types of conflict in this creative work. The first one is Man vs. Self which is "internal battles that characters wage within themselves; these are internal issues that affect their actions, motivations and interactions with other characters" (Arvind, 2013). The second one is Man vs. Man where characters "will be opposed by or will oppose the actions, reactions, motivations of another character" (Arvind, 2013). By including both types, this creative work highlights that low self-esteem issues can happen from factors both external (as seen in story one, two, and three) and internal (in story four and five).

\section{CONCLUSION}

The purpose of this creative work is to let readers know that children can develop low selfesteem from their surroundings like their family, teacher, and even the media. This is clearly shown in all five stories. Family members become the reason children develop low self-esteem issues in Ariana and Caroline's stories. A teacher causes low self-esteem in Benny's story while the mass media play that role in Dylan and Elena's stories.

The creative work also highlights that once children have overcome their problems, they will regain their self-esteem and, along with it, some positive effects. These are shown in the end of each story. Ariana feels more confident and loved by her mother because her mother finally acknowledges her ability, Benny feels happier because his teacher appreciates his art, Caroline is calmer when she has to sing since she has talked to her brother about the consequence of person praise, Dylan becomes more confident about his weight, and Elena is no longer insecure about her skin color. 
Adelia, et al.: Children Picture-Book Series on Exploring the Causes of Low Self-Esteem Issues in Children and the Positive Effects after Overcoming Them

\section{REFERENCES}

Ali, N.M. (2018, December 2). Mendikbud: Pembentukan karakter kercaya diri di Indonesia asih kurang. Siedoo. Retrieved from https://siedoo.com/berita-13071-mendikbud-pembentukan-karakter-percaya-diri-diindonesia-masih-kurang/

Alika, R. (2019, December 23). Nadiem menyatakan anak-anak Indonesia mengalami krisis percaya diri yang membuat mereka tak percaya dapat mencapai hal-hal yang luar biasa. Kata Data.

Baumeister, R.F. Vohs, K.D. (2018). Revisiting our reappraisal of the (surprisingly few) benefits of high self-esteem. Perspective on Psychological Science, 13(2), 137-140. doi: $10.1177 / 1745691617701185$

Brummelman, E. Crocker, J. Bushman, B.J. (2016). The praise paradox: Wwhen and why praise backfires in c hildren with low self-esteem. Child Development Perspectives, 10(2), 111-115. doi: $10.1111 /$ cdev. 12171

Cherry, K. (2019, September 5). Erik erikson's stages of psychosocial development. Retrieved October 5, 2019 , from https://www.verywellmind.com/erik-eriksons-stages-of-psychosocial-development 2795740

Danielsen, Y.S., Stormark, K.M., Nordhus, I.H., Mæhle, H., Sand, L., Ekornås, B., Pallesen, S. (2011). Factors associated with low self-esteem in children with overweight*. Obesity Facts, 5, 722-733. doi: $10.1159 / 000338333$

Damarjati, D. (2019, January 5). Benarkah minat baca orang Indonesia serendah ini? Detiknews. Retrieved from https://news.detik.com/berita/d-4371993/benarkah-minat-baca-orang-indonesia-serendah-ini

Grogan, S. (2017). Body image: Understanding body dissatisfaction in men, women and children. Routledge.

Hill, V.Z. (2013). Self-esteem. Psychology Press.

Knight, D. (2015). What's 'colorism'? Teaching Tolerance, (51). Retrieved from https://www.champaignschools.org/sites/default/files/Teaching\%20Tolerance\%2051\%20Whats\%20 Colorism.pdf

Makruf, M. (2016). Di balik buku: Peluang pasar buku Indonesia di pasar internasional. Retrieved October 4, 2019 , from http://jpbooks.id/di-balik-buku-peluang-pasar-buku-indonesia-di-pasar-internasional/

Master, A. (2015). Praise that makes learners more resilient. Retrieved from http://mindsetscholarsnetwork.org/wp-content/uploads/2015/09/Praise-That-Makes-Learners-MoreReslient.pdf

Paul, A.W. (2009). Writing picture books. Cincinnati, OH: Writer's Digest Books.

Polson, E. (2018). Realistic fiction books for kids and teens: a beginner's guide. Retrieved September 8, 2019, from https://bookriot.com/2018/06/25/realistic-fiction-books/

Pratiwi, P.S. (2018, March 27). Minat baca masyarakat Indonesia masih rendah. CNN Indonesia. Retrieved from https://www.cnnindonesia.com/gaya-hidup/20180326160959-282-285982/minat-bacamasyarakat-indonesia-masih-rendah

Prawira, A.E. (2018, April 17). Kepercayaan diri anak perempuan Indonesia rendah, apa sebabnya? Liputan6. Retrieved from https://www.liputan6.com/health/read/3462397/kepercayaan-diri-anak-perempuan-indonesia-rendahapa-sebabnya

Raina, S., \& Bhan, K.S. (2013). A study of security-insecurity feelings among adolescents in relation to sex, family system, and ordinal position. ISSN, (3)1, 51-60. Retrieved from https://www.ripublication.com/ijepa/ijepav3n1_05.pdf

Rodgers, R.F., Nichols, T.E., Stephanie, R., Wertheim, E.H., Paxton, S.J. (2019). Low body esteem and dietary restraint among 7-year old children: The role of perfectionism, low self-esteem, and belief in the rewards of thinness and muscularity. Eating Behaviors, 32, 65-68. doi:

10.1016/j.eatbeh.2018.12.004 
Self-Esteem, Ages 6 to 10. (2018, June 28). Retrieved from https://www.healthlinkbc.ca/health-topics/te6265

Stamps, D. (2018). Honors college thesis: the effects of skin tone on the perception of discrimination in young African American women (bachelor's thesis). The University of Southern Mississippi.

Wibisono, N. (2018, November 21). Melawan tren buku cerita anak di Indonesia. Retrieved October 4, 2019, from https://tirto.id/melawan-tren-buku-cerita-anak-di-indonesia-dajr

Worland, J. (2015, April 27). This is what happens when you read to a child. Time. Retrieved from https://time.com/3836428/reading-to-children-brain/ 